\title{
SPATIAL DISTRIBUTION OF BRACKISHWATER POND SOIL CHARACTERISTICS IN PEKALONGAN CITY CENTRAL JAVA PROVINCE
}

\author{
Andi Indrajaya Asaad\# and Akhmad Mustafa \\ Research Institute for Coastal Aquaculture, Maros
}

(Received 1 March 2011 ; Accepted 16 June 2011 )

\begin{abstract}
Spatial distribution of brackishwater pond soil has a vital role in the system of bioenvironment including brackishwater pond environment. This research was aimed to determine the spatial distribution of brackishwater pond soil characteristics in Pekalongan City, Central Java Province. A total of 59 sampling points each with two different soil depth samplings were determined by simple random method. A total of 21 soil characteristics were measured in the field and analyzed further in the laboratory. Geostatistic with Kriging Interpolation method in the ArcGIS 9.3 software were used to depict the distribution of the data across the landscape. Furthermore, the spatial distribution was presented by using ALOS AVNIR-2 image. Research result indicates that in general, pond soil in Pekalongan City can be classified as soil with high variability or relatively heterogenic with the value of variation coefficient more than $36 \%$. Soil characteristics which have similar pattern of spatial distribution are acid sulfate soil and soil nutrient content. High value of $\mathrm{pH}$, organic matter, and total$\mathrm{N}$ of soil, and on the other hand, low value of $\mathrm{PO}_{4}$ were generally found in the pond area of Krapyak Lor Village, while in Pekalongan City, it was found high clayish soil content but relatively homogenous. It is recommended that pond management must be based on soil characteristics which are different from one area to another. The soil characteristics itself can be drawn and assessed through spatial distribution.
\end{abstract}

KEYWORDS: spatial distribution, soil characteristic, brackishwater pond, Pekalongan City

\section{INTRODUCTION}

Ministry of Marine Affairs and Fisheries (MMAF) of the Republic of Indonesia has been focusing most of its resources to boost aquaculture production and to control capture fisheries. MMAF has targeted that the total aquaculture production at the end of 2014 should reach 16.8 million tonnes meaning the increase of aquaculture production up to $353 \%$. As being one of the main backbones of MMAF, aquaculture system consists of several subsector which are mariculture, brackishwater and freshwater aquaculture. For brackishwater system, it is estimated that 1.22 million hectares of land are suitable for brackishwater pond with the current utilization rate only 40\% (DKP, 2005). Based on the Decree of the Minister of Marine Affairs and Fisheries Number Kep.32/ Men/2010 on Specification Minapolitan Area, Pekalongan City (Central Java Province) has been appointed as one of the Minapolitan regions with shrimp as the core commodity.

\# Corresponding author. Research Institute for Coastal Aquaculture. Jl. Makmur Dg. Sitakka, Maros, Sulawesi Selatan 90512, Indonesia. Tel.: +62 411371544

E-mail address: andi_asaad1@yahoo.com 
Pekalongan City has a total area of 45.25 $\mathrm{km}^{2}$ located on the lowlands north coast of Java Island with approximately one meter above sea level and geographic position between 6 50 '42'"-6055'44' South latitude, and $109^{\circ} 37^{\prime} 55^{\prime \prime}-109^{\circ} 42^{\prime} 19^{\prime \prime}$ East longitude. The administrative boundaries is as follows: on the North: Java Sea; on the South: Regency of Pekalongan and Batang; on the West: Pekalongan Regency; on the East: Batang Regency. Pekalongan City is administratively divided into 46 self-sufficient village. These villages are located into 4 sub-districts namely West Pekalongan, East Pekalongan, South Pekalongan and North Pekalongan. Brackishwater ponds in Pekalongan City are only found on North Pekalongan Sub-district with the total area approximately 332.29 ha (Rachmansyah et al., 2010). In addition, other types of land use besides brackishwater ponds in coastal areas of North Pekalongan Subdistrict are paddy field, intrusion paddy field and residential with total area of 372.53 ; 183.83; and 619.73 ha respectively.

One of the environmental factors that affect the productivity of brackishwater ponds is soil quality. Soil quality is a major production factor in aquaculture because it can affect water quality, biological and engineering processes of ponds (Boyd, 1995; Sammut, 1999). Therefore, soil quality has been generally considered in the evaluation of land suitability for aquaculture (Muir \& Kapetsky, 1988; Boyd, 1995; Treece, 2000; Salam et al., 2003; Karthik et al., 2005; Mustafa et al., 2007).

Spatial distribution of soil characteristics has an important role in bio-environmental system (Rossi et al., 1992; Zuo et al., 2008; Dong et al., 2009; Akbarzadeh \& TaghizadehMehrjardi, 2010; Zare-Mehrjardi et al., 2010). Knowledge of spatial variability of soil characteristics and its relationship are important for the evaluation of land management practices (Huang et al., 2001) and increased sustainability of land use (Liu et al., 2006). Variability is one of the core soil quality characteristics and in the same ecosystem soil quality may show significant spatial variations (Robinson \& Metternicht, 2006). These variations have mainly arisen from the factors and the process of pedogenesis and land use type (Ersahin, 2003; Liu et al., 2006) and soil management practices (Anuar et al., 2008) as well as structure of topography (Liu et al., 2006). However, by applying classical statistics which consider the soil dataset as an independent, their implementations lead very often to unrealistic results (Hasany-Pak, 1998 in ZareMehrjardi et al., 2010). Furthermore, on the contrary assumption when applying the classical statistics is that the soil characteristics in a landscape are not distributed randomly (variability has not only random but also has not correlated to the spatial location) (Essington, 2004).

Natural soil characteristics can vary continuously in a particular time and place. In this conditions, soil quality is very difficult to measure at any point in the field continuously (Madyaka, 2008). Geostatistics can be used to characterize and measure the spatial variability of soil characteristics as well as to interpolate rationally and estimate the difference of the interpolated values (Lin et al., 2001; Essington, 2004). Therefore, geostatistical methods need to be applied in order to understand the spatial distribution of soil characteristics of the brackishwater pond in the Pekalongan City Central Java Province. This will finally reach to a conclusion that land management can be done in accordance with the characteristics of the brackishwater pond soil. Proper land management can increase the productivity of land, including ponds aquaculture with a minimum use of inputs and environmental degradation.

\section{MATERIAL AND METHOD}

\section{Research Location}

This experiment was conducted at the coastal region of North Pekalongan sub-district Pekalongan City Central Java Province, Indonesia (Figure 1) in October 2009. At the first stage, the research was initiated in the form of discussions with staff of the Department of Agriculture, Animal Husbandry and Marine Pekalongan City to obtain general information of aquaculture land use in Pekalongan City.

\section{Data Collection}

\section{Primary data}

The primary data were collected covering biophysical data which was soil data. Soil sampling stations were determined by simple random sampling on 59 stations (Figure 1). Variables of soil quality measured directly in the field were $\mathrm{pH}_{\mathrm{F}}$ (soil $\mathrm{pH}$ measured in the field) 


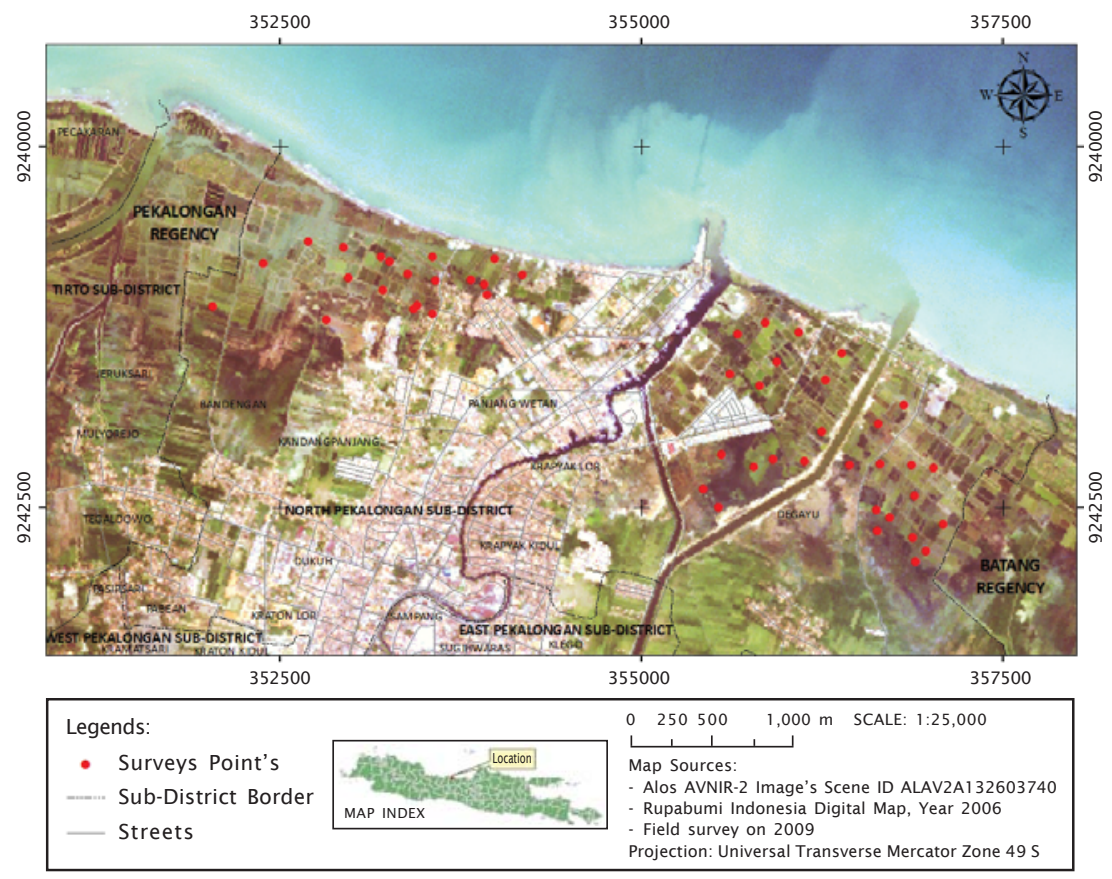

Figure 1. Soil sampling points in the coastal zone of North Pekalongan subdistrict Pekalongan City Central Java Province

with a pH-meter (Ahern \& Rayment, 1998), $\mathrm{pH}_{\mathrm{FOX}}$ (soil $\mathrm{pH}$ measured in the field after oxidized with hydrogen peroxide $\left(\mathrm{H}_{2} \mathrm{O}_{2}\right) 30 \%$ ) with $\mathrm{pH}$ meter (Ahern \& Rayment, 1998) and redox potential with redox-meter.

\section{Sampling Points}

Soil samples were taken at two soil depths, which are 0 to $0.2 \mathrm{~m}$ and 0.5 to $0.7 \mathrm{~m}$ from ground level. For further analysis the soil samples were immediately placed in plastic bags and stored in a cool box. This had to be performed because some of the samples were classified as acid sulfate soil. Furthermore the soil samples were dried at $80^{\circ} \mathrm{C}-85^{\circ} \mathrm{C}$ for 48 hours (Ahern \& Blunden, 1998) for acid sulfate soil and non-acid sulfate alluvial soil samples were dried naturally. After dried, soil samples were pounded on porcelain mortar and sieved with $2 \mathrm{~mm}$ size sieve then analyzed at the Soil Laboratory of Research Institute for Coastal Aquaculture (RICA) in Maros. The analyzed parameters were $\mathrm{pH}_{\mathrm{KCl}}(\mathrm{pH}$ of the $\mathrm{KCl}$ extract) (McElnea \& Ahern, 2004a), $\mathrm{pH}_{\mathrm{ox}}$ (McElnea \& Ahern, 2004b), $S_{p}$ (sulfur peroxide) (Melville, 1993; McElnea \& Ahern, 2004c), $S_{\mathrm{KCl}}$ (sulfur was extracted with $\mathrm{KCl}$ ) (Melville, 1993; McElnea \&
Ahern, 2004d), $S_{\text {POS }}\left(S_{\mathrm{P}}-S_{K C l}\right)$ (Ahern \& McElnea, 2004), TPA (Peroxide Titratable Acidity or formerly known as Total Potential Acidity) (McElnea \& Ahern, 2004b), TAA (Actual Titratable Acidity or formerly known as Total Actual Acidity) (McElnea \& Ahern, 2004a), TSA (Titratable Sulfidic Acidity or formerly known as Total Sulfidic Acidity) (TPA-TAA) (McElnea \& Ahern, 2004b), $\mathrm{FeS}_{2}$ (pyrite) (Ahern et al., 1998a, 1998 b), organic carbon by Walkley and Black method (Sulaiman et al., 2005), total-N (totalnitrogen) by Kjedhal method (Sulaiman et al., 2005), $\mathrm{PO}_{4}$ (phosphate) with Bray 1 or Olsen method (Sulaiman et al., 2005), Fe (iron) which was measured by spectrophotometer (Menon, 1973), Al (aluminium) (measured by spectrophotometer) (Menon, 1973), and texture by hydrometer method (Agus et al., 2006).

\section{Secondary Data}

Secondary data were collected through review of literature and research results from various relevant institutes. Maps were compiled include Indonesia topography map scaled of 1:50,000) with an index number 1409112 (Pekalongan) and Administrative map of Pekalongan City. 


\section{Data Analysis}

Land use/cover map was taken from image classification of ALOS (Advanced Land Observing Satellite) AVNIR-2 (The Advanced Visible and Near Infrared Radiometer type 2) acquisition of July 21,2008 . These were processed by ErMapper 1.7 software and integrated with basic map of Indonesia topography map. Other spatial information derived from primary and secondary data were also integrated with the land used map.

Soil characteristics data were analyzed using classical statistical methods to get the minimum, maximum, average, standard deviation, coefficient of variation, kurtosis and skewness based on the instructions Sokal \& Rohlf (1981). In order to interpolate these data, particularly for soil at depth of 0 to $0.2 \mathrm{~m}$, Kriging method in ArcGIS 9.3 was used. Kriging is a common method in geostatistical interpolation process of soil characteristic data (Yost et al., 1982; DeBusk et al., 1994; Lin, 2008).

\section{RESULT AND DISCUSSION}

Coefficient variation of brackishwater pond soil for $\mathrm{pH}_{\mathrm{KCl}}$ varied from the lowest (5.34\%) and highest for TPA, TSA and pyrite (146.72\%) for soil depths of 0 to $0.2 \mathrm{~m}$ (Table 1). The lowest coefficient variation was in $\mathrm{pH}_{\mathrm{F}}(9.26 \%)$ and highest in the TSA and pyrite (135.89\%) for soil depth from 0.5 to $0.7 \mathrm{~m}$ (Table 2). It has been reported by Goh et al. (1998) that the coefficient variation of soil characteristics in Sabah (Malaysia) exceeded $100 \%$ on the same soil series.

Based on the classification established by Essington (2004), the variables, that were categorized as small or relatively homogeneous, were $\mathrm{pH}_{\mathrm{F}}$ and $\mathrm{pH}_{\mathrm{KCl}}$. Middle variability was the content of clay fractions while other soil quality variables considered as high or relatively heterogeneous variability particularly for the depth of 0 to $0.2 \mathrm{~m}$. At the depth of 0.5 to $0.7 \mathrm{~m}$, the variables which were categorized as small variability were $\mathrm{pH}_{\mathrm{F}}, \mathrm{pH}_{\mathrm{KCl}}$ and content of clay fractions, whereas the other soil quality variables were considered high variability. This indicates that the overall characteristic of the brackishwater pond soil in the Pekalongan City was relatively high or relatively heterogeneous variability. Essington (2004) stated that the characteristics of soils are highly variable relative to location on the landscape and depth within the profile. High variability of soil characteristics in the same soil series have also been reported in Peninsular Malaysia by Law \& Tan (1977).

The types of brackishwater soil in Pekalongan are non-acid sulfate alluvial soil and a few of acid sulfate soil with little gray color. Acid sulfate soil is mostly found at Krapyak Lor Village. Vertical spatial distribution of brackishwater ponds soil in Pekalongan City is shown in Tables 1 and 2 and horizontal distribution is presented in Figure 1, 2, 3, and 4.

Redox potential describes the condition of oxidized soil. Redox potential is the result of quantitative measurements to inform a diagnostic index of anaerobic or soil anoxia (Patrick \& Delaune, 1977). Table 1 depicts the soil redox potential at depths of 0 to $0.2 \mathrm{~m}$ higher than the depth of 0.5 to $0.7 \mathrm{~m}$. This is because of the drying of brackishwater pond bottom is usually done by farmers at the time of preparation where the surface of the brackishwater pond has become dry and increasing soil redox potential compared to the existing soil beneath. Figure 2 shows higher redox potential found in brackishwater pond soil of Degayu Village. Presumably, low organic matter in these locations had caused higher redox potential. Organic matter is a kind of material that has the ability to hold water, so the chance of lower redox potential may occur in particular areas that contain high organic matter. In general, brackishwater pond soil in the Pekalongan City is categorized as educed conditions. This was as a result of soil sampling conducted at the time where brackishwater pond in the process of cultivation of shrimp and milkfish either monoculture or polyculture, so the brackishwater ponds were full of water.

$\mathrm{pH}_{\mathrm{F}}$ can be used as an indicator to measure the presence and severity of the actual acid sulfate soil. In general, relatively high $\mathrm{pH}_{\mathrm{F}}$ soil can be found at the depth of 0 to $0.25 \mathrm{~m}$ than the soil depth of 0.5 to $0.7 \mathrm{~m}$. It is assumed as the result of natural leaching process in a relatively long period of time that has caused the reduction of soil acidity compounds on the surface. In addition, land management practices such as the use of limestone by farmers cause high $\mathrm{pH}_{\mathrm{F}}$ on surface soil. It has been reported by de Queiroz et al. (2004) that the application of lime in soil surface can significantly affect the soil to depth of $0.04 \mathrm{~m}$. At 0 to $0.25 \mathrm{~m}$ soil depth, the spatial distribution of relative $\mathrm{pH}_{\mathrm{F}}$ was the same as shown in Figure 2 


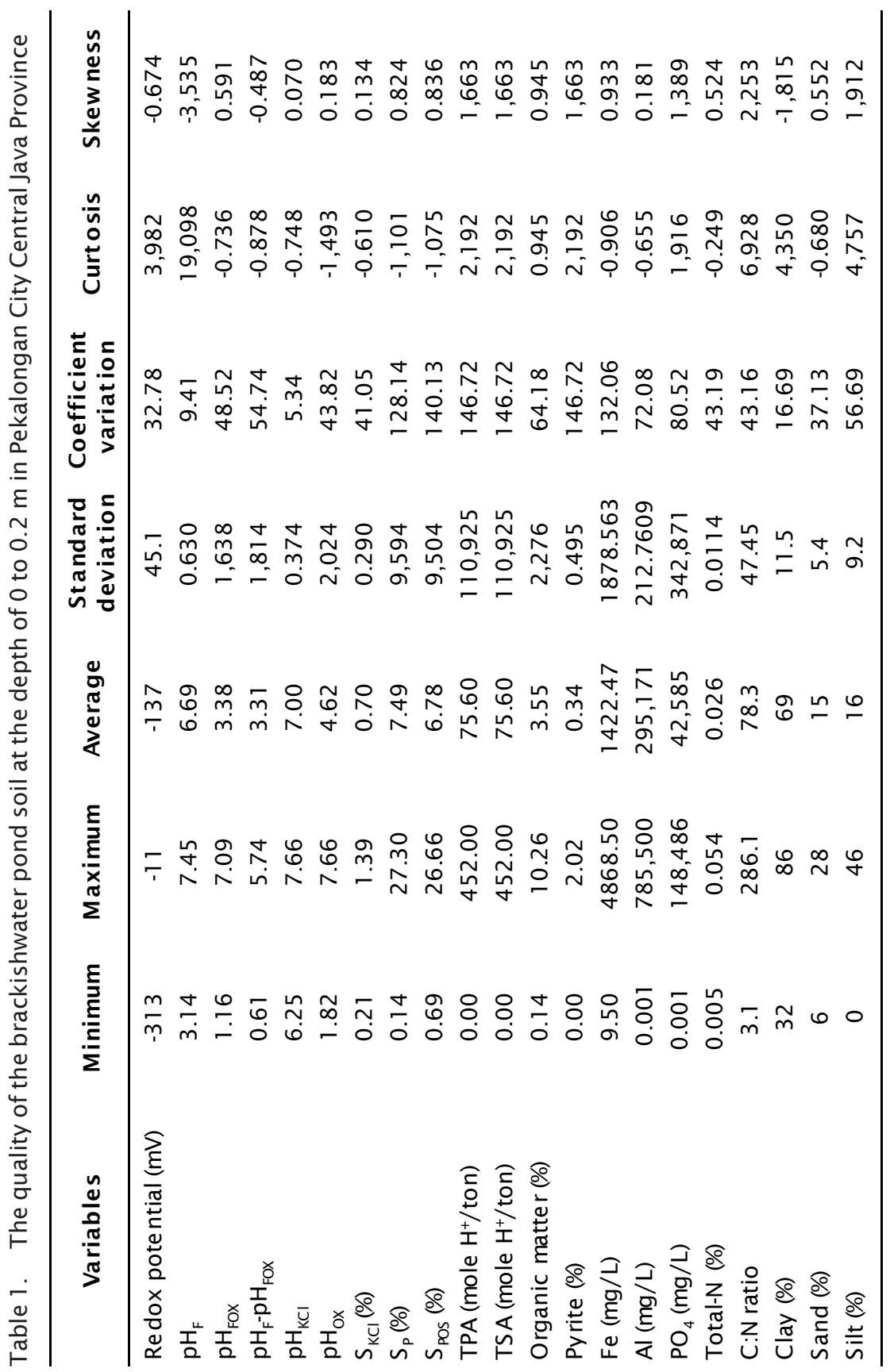




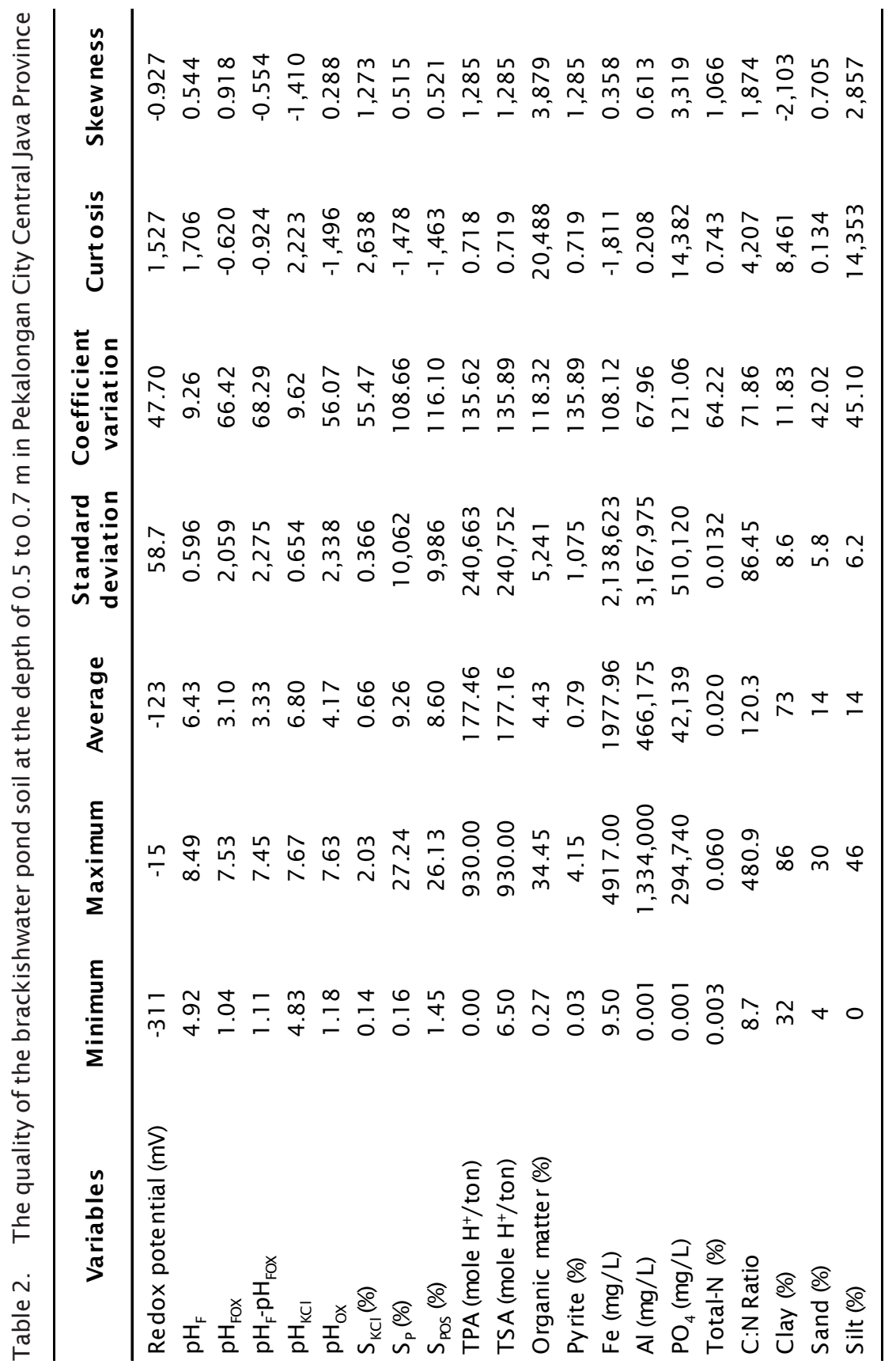


and also indicated by the relatively low coefficient of variation as shown in Table 1 or relatively homogeneous in other words.
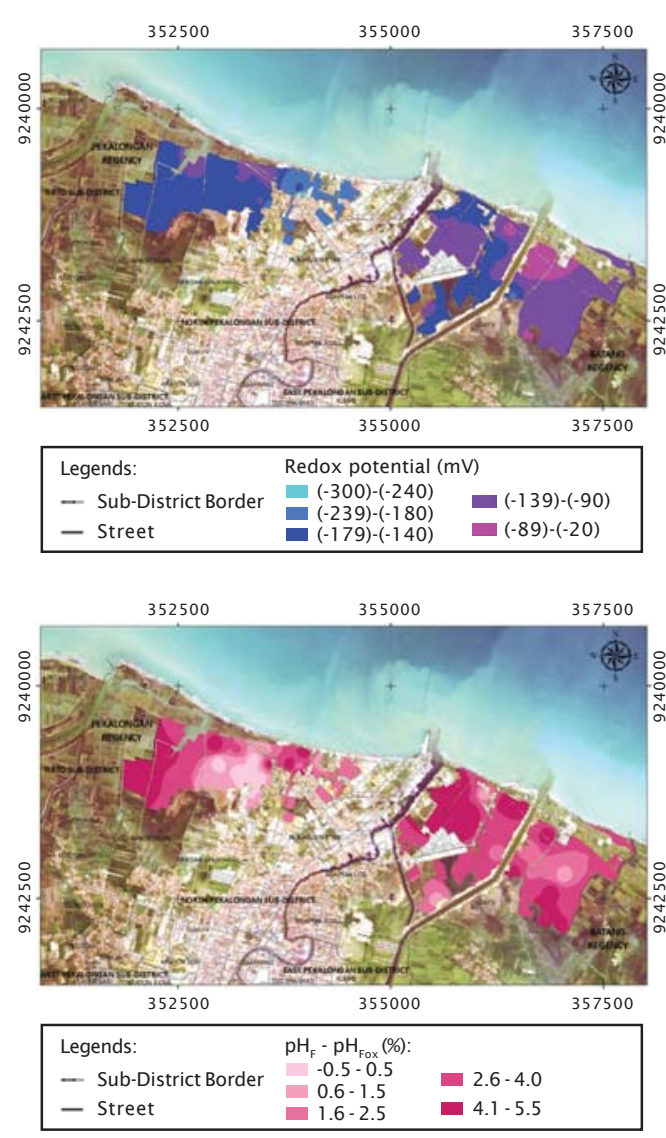

Characteristic of non-acid sulfate alluvial soil is clearly seen in Table 1 where $\mathrm{pH}_{\mathrm{F}}-\mathrm{pH}_{\text {FOx }}$ is not too high. It was also found in the soil
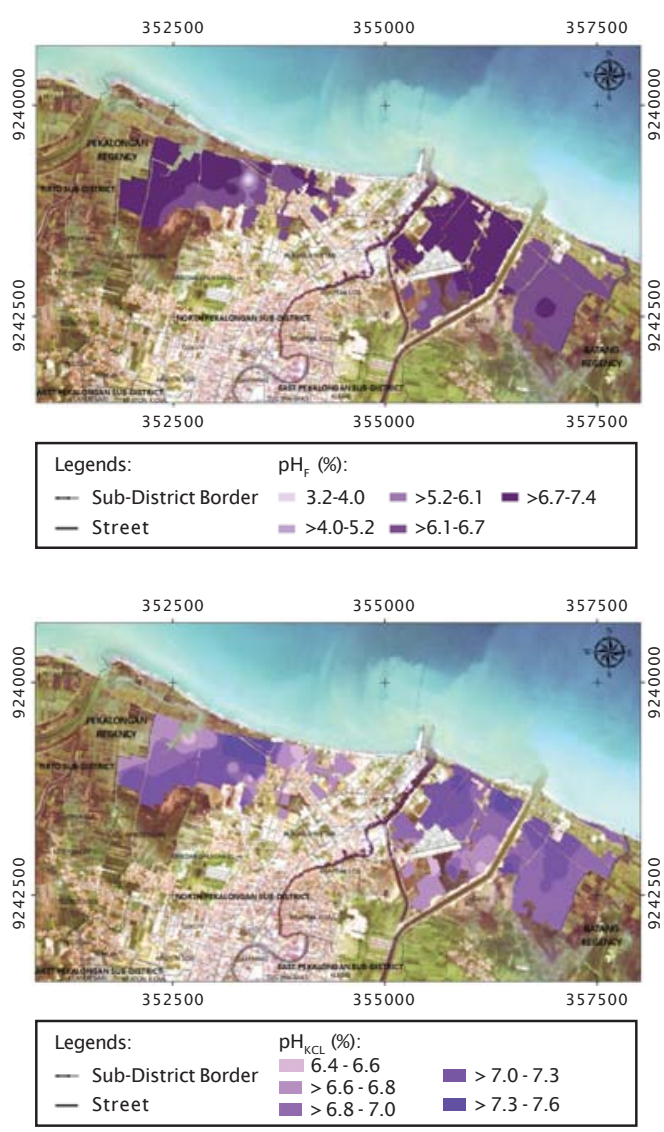

355000

357500

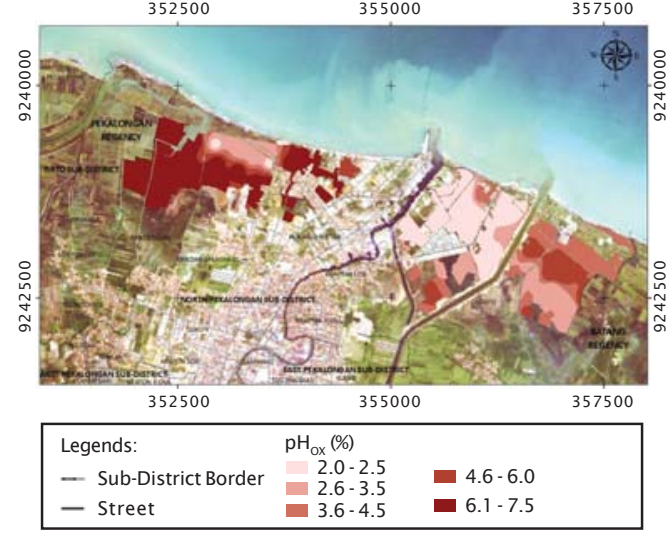

Figure 2. Spatial distribution map of redox potential (top left), $\mathrm{pH}_{\mathrm{F}}$ (top right), $\mathrm{pH}_{\mathrm{F}}-\mathrm{pH}_{\mathrm{FOX}}($ left center), $\mathrm{pH}_{\mathrm{KCl}}$ (right center), and $\mathrm{pH}_{\mathrm{ox}}$ (bottom) of brackishwater pond soil at 0 to $0.2 \mathrm{~m}$ depth in Pekalongan City Central Java Province 
depth of 0.5 to $0.7 \mathrm{~m}$ (Table 2 ). $\mathrm{pH}_{\mathrm{F}}$ is soil $\mathrm{pH}$ which is measured in the field at the condition of soil saturated with water, while $\mathrm{pH}_{\mathrm{FOX}}$ is soil $\mathrm{pH}$ which is measured in the field after being oxidized perfectly with $\mathrm{H}_{2} \mathrm{O}_{2} 30 \%$ (Ahern \& Rayment, 1998). $\mathrm{pH}_{\mathrm{F}}-\mathrm{pH}_{\mathrm{FOX}}$ can be used to determine the potential of existing acidity in the soil. In the acid sulfate soil, $\mathrm{pH}_{\mathrm{F}}-\mathrm{pH}_{\mathrm{FOx}}$ may
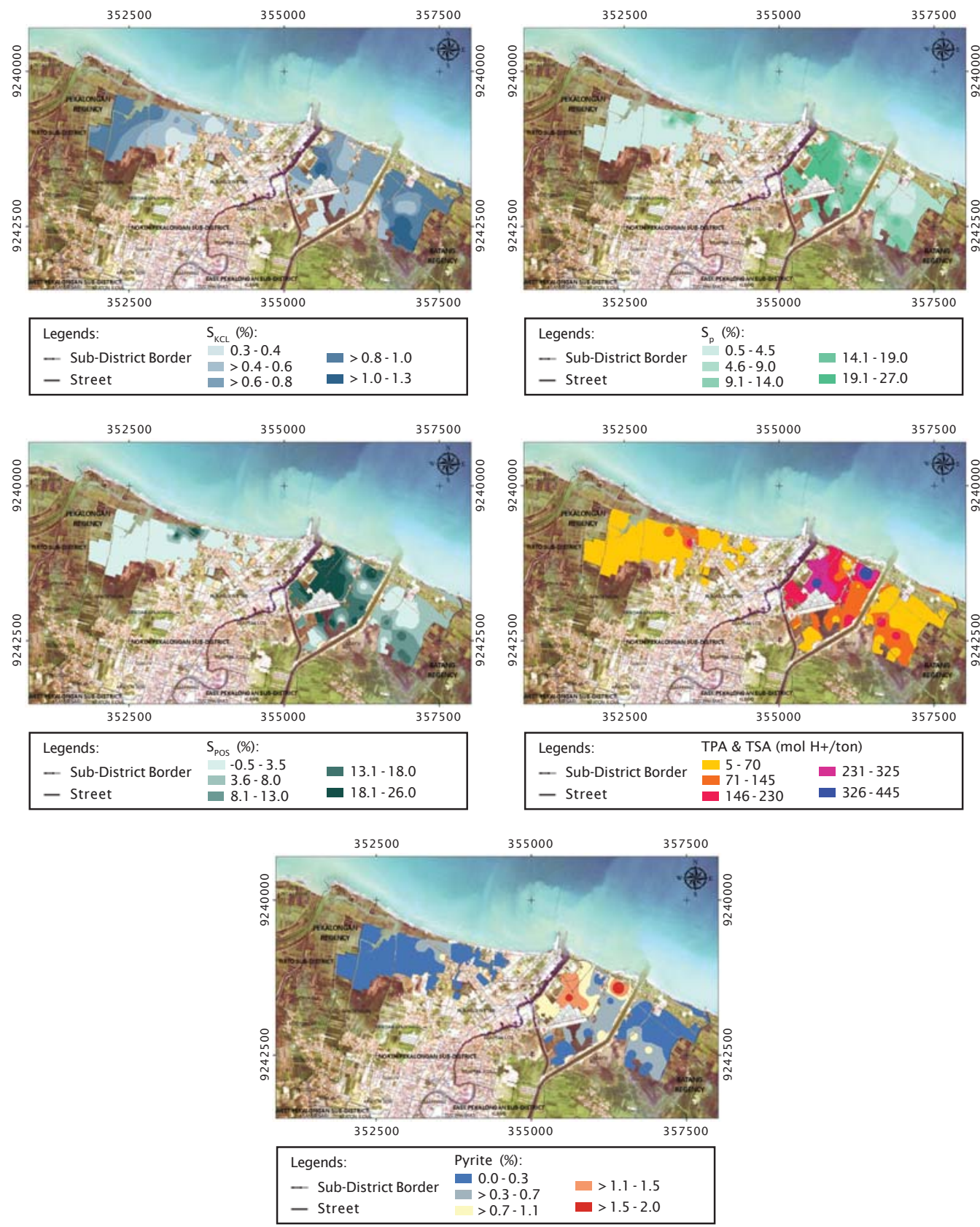

Figure 3. Spatial distribution map of $\mathrm{S}_{\mathrm{KCl}}$ (top left), $\mathrm{S}_{\mathrm{P}}$ (top right), $\mathrm{S}_{\mathrm{POS}}$ (left center), TPA and TSA (right center) and pyrite (bottom) of brackishwater pond soil at 0 to $0.2 \mathrm{~m}$ depth in Pekalongan City Central Java Province 
exceed the value 5 (Mustafa \& Rachmansyah, 2008). Figure 2 shows that values of $\mathrm{pH}_{\mathrm{F}}-\mathrm{pH}_{\mathrm{FOX}}$ were high enough in the brackishwater pond areas of Pekalongan City. These areas were distributed in Krapyak Lor Village. Similar spatial distribution pattern of $\mathrm{pH}_{\mathrm{F}}-\mathrm{pH}_{\mathrm{FOX}}$ was detected in the spatial distribution of the $\mathrm{pH}_{\mathrm{Ox}}$. However, in areas where high $\mathrm{pH}_{\mathrm{F}}-\mathrm{pH}_{\mathrm{FOx}}$ was
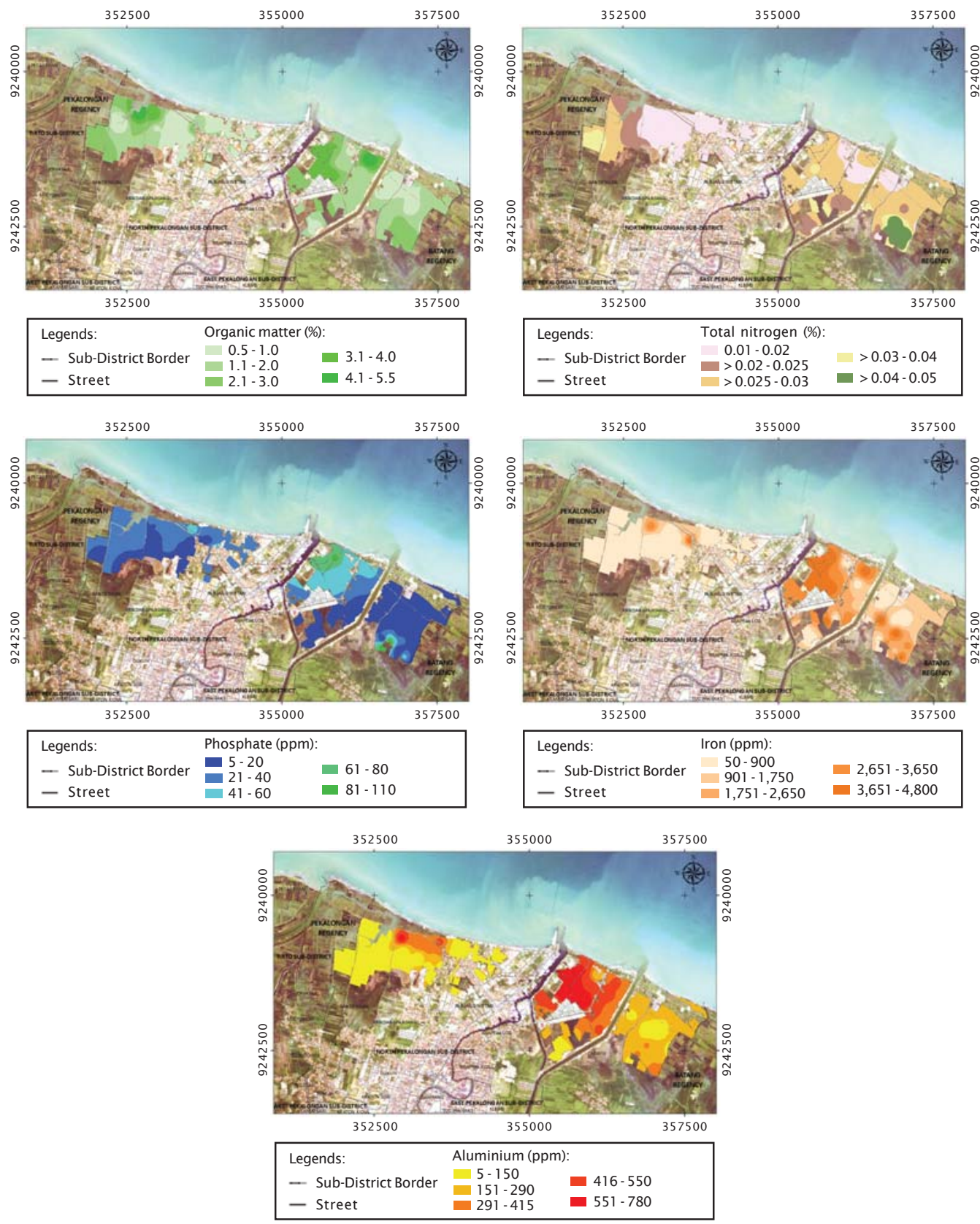

Figure 4. Spatial distribution map of organic matter (top left), total-N (top right), $\mathrm{PO}_{4}$ (left center), iron (right center), and aluminum (bottom) of brackishwater pond soil at 0 to $0.2 \mathrm{~m}$ depth in Pekalongan City Central Java Province 
detected the $\mathrm{pH}_{\mathrm{ox}}$ was low. $\mathrm{pH}_{\mathrm{ox}}$ is the $\mathrm{pH}$ of soil which has been dried and then oxidized with $\mathrm{H}_{2} \mathrm{O}_{2} 30 \%$ (McElnea \& Ahern, 2004b), thus describing the full potential of existing acidity in the soil.

Spatial distribution of organic matter also has the same pattern with $\mathrm{pH}_{\mathrm{F}}-\mathrm{pH}_{\mathrm{FOx}}$. This explains that the potential of soil acidity in the pond of Pekalongan City was generally derived from organic matter. Presumably, high organic matter is derived from mangrove vegetation which has been converted to brackishwater pond or growing mangrove vegetation in the pond. It was reported by Rachmansyah et al. (2010) that mangrove vegetations found around Krapyak Lor Village were dominated by mangrove species of Rhizophora mucronata and Nipah (Nypa fruticans). Falling leaves is the largest contributor to organic matter in sediments of mangrove forests (Koch, 2005). Decomposition of organic matter produces humus acids that cause the soil $\mathrm{pH}$ to become lower. Another possibility of high potential soil acidity in mangrove vegetation is because of the high content of tannin from Rhizophora sp., Bruguiera sp., Ceriops tagal, Xylocarpus granatum, and Nypa fruticans causing the soil to become more acidic (Sunarto, 2008). Thus, it was assumed that the utilization of the particular areas such as mangrove areas can cause the variation of soil organic matter. Land use type is one of the factors that cause the variation of soil organic matter (Liu et al., 2006).

Results of other variables that describe the soil acidity are $\mathrm{S}_{\mathrm{KCI}}, \mathrm{S}_{\mathrm{P}}, \mathrm{S}_{\mathrm{POS}}$, TPA, and TSA. They showed the same relative spatial distribution with other soil acidity variables such as $\mathrm{pH}_{\mathrm{F}}$ $\mathrm{pH}_{\mathrm{FOx}}$. Figure 3 shows that the highest value of $S_{K C I}, S_{P}, S_{\text {POS }}$, TPA, and TSA were found in the soil located in the Krapyak Lor Village. It has been mentioned previously that acid sulfate soil in the brackishwater pond of Pekalongan City found at Krapyak Lor Village. McElnea et al. (2002a, 2002b) stated that in the acid sulfate soil, especially containing a low organic matter, the TSA correlates significantly with the $S_{\text {POS. }}$. TSA also has a linear relationship with the content of pyrite (Sutrisno, 1990 in Noor, 2004) in acid sulfate soil. Variables that describe soil acidity were generally lower at 0 to $0.25 \mathrm{~m}$ soil depth than the depth of 0.5 to 0.7 $\mathrm{m}$. Soil properties differ according to depth due to the process of horizonation (Essington, 2004). As also previously described that natural leaching in the long term can cause the reduction of compounds or elements causing the acidity. It has been reported by Mustafa (2007) that the $S_{\text {pOS }}$ of pond bottom soil decreased from $2.1300 \%$ to $1.8587 \%$ or declined $0.2713 \%$ after the brackishwater pond bottom soil was remediated three times in the period of 72 days.

Pyrite is the main characteristic of acid sulfate soil. Relatively high amount of pyrite was only found at Krapyak Lor Village (Figure 3). Factors that influence the formation of pyrite are the amount of organic matter, sediment temperature, the supply of $\mathrm{SO}_{4}$ and bicarbonate as well as anaerobic condition and amount of Fe (Dent, 1986). The high amount of pyrite in this village was the result of high organic matter content (Figure 4), a carbon source for bacteria for pyrite formation. In addition, Noor (2004) stated that clay deposits were derived from the fibers of remaining mangrove root. These deposits contain high pyrite. This is supported by Ersahin (2003) that variations in soil characteristics are not only as the result of land use type, but also the process of pedogenesis (soil formation).

As mentioned earlier, the soil organic matter was found relatively high in Krapyak Lor Village. It was also found in Bandengan Village, particularly in a specific area. However, the areas in both villages were not yet classified as peat soils because organic matters were lower than $20 \%$. Peat soil is type of soil containing organic matter more than $20 \%$ (if the soil does not contain clay) or more than $30 \%$ (if the soil contains clay equal or greater than 60\%) (Soil Survey Staff, 2001).

Spatial distribution of soil nutrient in the brackishwater ponds of Pekalongan City is shown in Figure 4. This shows that organic matter, total-N, Fe and Al have the similar relative distribution pattern. Organic matter does not only serve as the source of carbon, but also as a source of nitrogen (Boyd, 2008). Thus, the high content of total- $\mathrm{N}$ in the area of high soil organic matter can be explained as the result of the decomposition process of organic matter which produces nitrogen. Higher content of $\mathrm{Fe}$ and $\mathrm{Al}$ in the area of high organic matter is an impact of low pH that causes a higher solubility of those toxic elements. The content of $\mathrm{Al}$ in acid sulfate soil increased at lower pH, i.e. pH 4.0 to 4.5 (Dent, 1986).

In addition, the content of $\mathrm{Al}$ in acid sulfate soil is associated with pyrite oxidation. The 
acid environment has accelerated weathering of alumino-silicate minerals due to the destruction of the lattice of the $2: 2$ type minerals (such as montmorillonite) to become 1:1 type minerals (kaolinite) to liberate and dissolve more $\mathrm{Al}$ (Pons, 1973). The content of $\mathrm{Fe}$ and $\mathrm{Al}$ were high in Krapyak Lor Village causing lower $\mathrm{PO}_{4}$ (phosphate). This is as the result of Fe and $\mathrm{Al}$ which affects $\mathrm{PO}_{4}$ to be unavailable. At low soil $\mathrm{pH}, \mathrm{PO}_{4}$ is bounded strongly by $\mathrm{Fe}$ and $\mathrm{Al}$ in the form of insoluble $\mathrm{FePO}_{4}$ or $\mathrm{AlPO}_{4}$ (Kselik et al., 1992, Tu et al., 1993; Mustafa \& Sammut, 2007). Figure 4 shows that low $\mathrm{PO}_{4}$ that was found in areas contained high $\mathrm{Fe}$ and $\mathrm{Al}$.

Soil texture is the ratio between the fraction of clay, silt and sand within the soil. Pond soil texture affects the porosity and growth of klekap where the latter is the source of food for fish and shrimp. Fine textured brackishwater pond soils are often found in areas where clay content ranges from $20 \%$ to $30 \%$ which can resist water infiltration into the pond (Boyd, 1995). Boyd (1995) also states that a soil material consisting of a mixture of particles of different sizes and containing a minimum of $30 \%$ clay is ideal for brackishwater pond construction.

In general, soil clay distribution in the brackishwater pond of Pekalongan City can be classified as heavy clay texture or have a very high clay content. Particularly, high content of clay and therefore lower content of silt and sand fractions were found in areas of Kandang Panjang, Krapyak Lor, and Degayu Villages (Figure 5). However, the content of clay fractions was relatively homogeneous which indicated by a relatively small coefficient variation ranging from 0.5 to $0.7 \mathrm{~m}$ soil depth (Table 2 ).
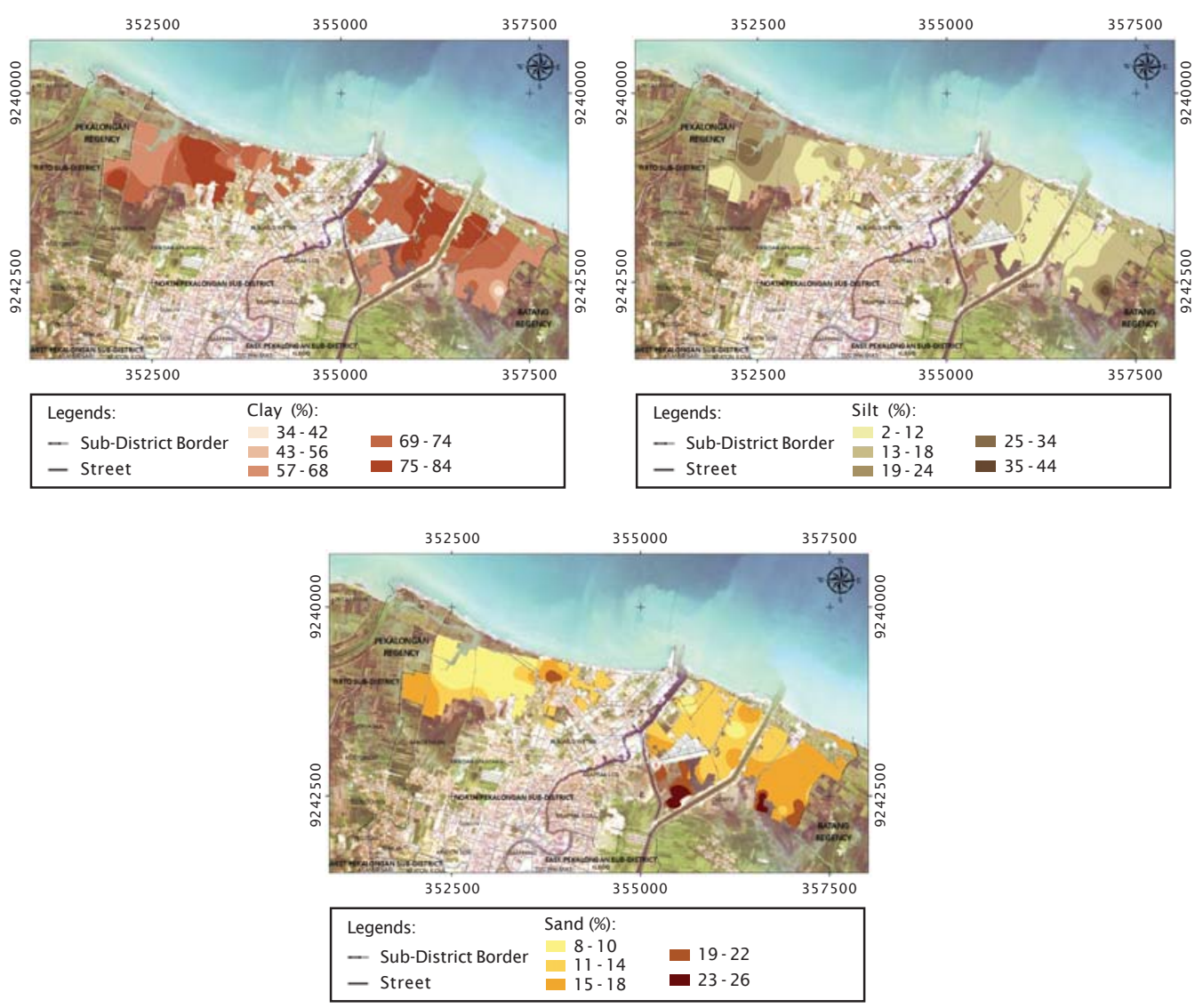

Figure 5. Spatial distribution map of clay fractions (top left), silt (top right) and sand (bottom) of brackishwater pond soil depth from 0 to $0.2 \mathrm{~m}$ in Pekalongan City Central Java Province 


\section{CONCLUSIONS AND SUGGESTIONS}

Brackishwater pond soil in Pekalongan City is classified into non-sulfate alluvial soil without potential high soil acidity. Acid sulfate soil fraction mostly was found in Kropyak Lor Village. In general, brackishwater pond soil characteristics are considered to have high or relatively heterogeneous variability with coefficient variation more than $36 \%$. Soil characteristics that describe the pattern of soil acidity relatively have the same spatial distribution. In addition, soil characteristics that describe the nutrient content of soil also have a similar spatial distribution pattern.

The high content of soil $\mathrm{pH}$, organic matter, and total- $\mathrm{N}$ and conversely low $\mathrm{PO}_{4}$ content was generally found in ponds of Krapyak Lor Village. The clay fractions were relatively homogeneous in pond soil of Pekalongan City. The typical pattern of spatial distribution of the brackishwater pond soil characteristics in Pekalongan City can be caused by the process of pedogenesis, land use type and land management practices. It is recommended that pond management should be tailored to the characteristics of the soil which is reflected by the pattern of spatial distribution of each soil characteristics.

\section{ACKNOWLEDMENT}

Special acknowledgment for Makmur, Rosiana Sabang and Ilham for their support in the measurement and soil sampling in the field as well as Kamariah, Rahmiyah, and Rismawati for their assistance in the analysis of soil quality in the laboratory. We also thank to the Head of Agriculture, Animal Husbandry and Marine Department of Pekalongan City and all of the staffs for any assistance and support during this research.

\section{REFERENCES}

Agus, Yusrial, F., \& Sutono. 2006. Penetapan tekstur tanah. Dalam: Kurnia, U., Agus, F., Adimihardja, A. \& Dariah, A. (eds.), Sifat Fisik Tanah dan Metode Analisisnya. Balai Besar Penelitian dan Pengembangan Sumberdaya Lahan Pertanian, Bogor, p. 43-62.

Ahern, C.R. \& Blunden. B. 1998. Designing a soil sampling and analysis program. In: Ahern, C.R., Blunden, B., \& Stone, Y. (eds.) Acid Sulfate Soils Laboratory Methods Guidelines. Acid Sulfate Soil Management
Advisory Committee, Wollongbar, NSW, p. 2.1-2.6.

Ahern, C.R. \& McElnea, A.E. 2004. Calculated sulfur parameters. In: Acid Sulfate Soils Laboratory Methods Guidelines. Queensland Department of Natural Resources, Mines and Energy, Indooroopilly, Queensland, Australia, p. B1 1-1-B11-2.

Ahern, C.R., McElnea, A., \& Baker, D.E. 1998a. Peroxide oxidation combined acidity and sulfate. In: Ahern, C.R., Blunden, B., \& Stone, Y. (eds.) Acid Sulfate Soils Laboratory Methods Guidelines. Acid Sulfate Soil Management Advisory Committee, Wollongbar, NSW, p. 4.1-4.17.

Ahern, C.R., McElnea, A., \& Baker, D.E. 1998b. Total oxidisable sulfur. In: Ahern, C.R., Blunden, B., \& Stone, Y. (eds.) Acid Sulfate Soils Laboratory Methods Guidelines. Acid Sulfate Soil Management Advisory Committee, Wollongbar, NSW, p. 5.1-5.7.

Ahern, C.R. \& Rayment, G.E. 1998. Codes for acid sulfate soils analytical methods. In: Ahern, C.R., Blunden, B., \& Stone, Y. (eds.) Acid Sulfate Soils Laboratory Methods Guidelines. Acid Sulfate Soil Management Advisory Committee, Wollongbar, NSW, p. 3.1-3.5.

Akbarzadeh, A. \& Taghizadeh-Mehrjardi, R. 2010. Spatial Distribution of Some Soil Properties, Using Geostatistical Methods in Khezrabad Region (Yazd) of Iran. ProEnvironment, 3: 100-109.

Anuar, A.R., Goh, K.J., Heoh, T.B., \& Ahmed, O.H. 2008. Spatial Variability of Soil Inorganic N in a Mature Oil Palm Plantation in Sabah, Malaysia. American J. of Applied Sciences, 5(9): 1,239-1,246.

Boyd, C.E. 1995. Bottom Soils, Sediment, and Pond Aquaculture. Chapman and Hall, New York, $348 \mathrm{pp}$.

Boyd, C.E. 2008. Pond bottom soil analyses. Global Aquaculture Advocate September/ October, p. 91-92.

Dent, D. 1986. Acid Sulphate Soils: A Baseline for Research and Development. ILRI Publication 39. International Institute for Land Reclamation and Improvement, Wageningen, $204 \mathrm{pp}$.

DeBusk, W.F., Reddy, K.R., Koch, M.S., \& Wang, Y. 1994. Spatial distributions of soil nutrients in a Northen Everglades Marsh: Water Conservation Area 2A. Soil Science Society of American J., 58: 543-552. 
DKP (Departemen Kelautan dan Perikanan). 2005. Revitalisasi Perikanan Budidaya. Departemen Kelautan dan Perikanan, Jakarta, $275 \mathrm{pp}$.

Dong, X.W., Zhang, X.K., Bao, X.L., \& Wang, J.K. 2009. Spatial distribution of soil nutrients after the establishment of sand-fixing shrubs on sand dune. Plant Soil Environment, 55(7): 288-294.

Ersahin, S. 2003. Comparing ordinary kriging and cokriging to estimate infiltration rate. Soil Science, 67: 1,848-1,855.

Essington, M.E. 2004. Soil and Water Chemistry: An Integrative Approach. CRC Press, Boca Raton, 534 pp.

Goh, K.J., Kee, K.K., \& Chew, P.S. 1998. Soil fertility status of some common soils in Sabah, Malaysia. In: Aziz, B. \& Husni, A.M.S. (eds.), Proceedings of the Soil Science Conference of Malaysia. Malaysian Society of Soil Society, Kuala Lumpur, p. 1-16.

Huang, X., Skidmore, E.L., \& Tibke, G. 2001. Spatial variability of soil properties along a transect of CRP and continuously cropped land. In: Stott, D.E., Mohtar, R.E., \& Steinhardt, G.C. (eds.), Sustaining the Global Farm. Selected papers from $10^{\text {th }}$ International Soil Conservation Organization Meeting held May 24-29, 1999 at Purdue University and the USDA-ARS National Soil Erosion Research Laboratory, p. 641-647.

Karthik, M., Suri, J., Saharan, N., \& Biradar, R.S. 2005. Brackishwater aquaculture site selection in Palghar Taluk, Thane district of Maharashtra, India, using the techniques of remote sensing and geographical information system. Aquacultural Engineering, 32: 285-302.

Koch, B.P. 2005. Organic Matter Pathways in a Mangrove System in Northen BrazilChemical Tracers of Major Sources under the Influence of Sedimentation and Biological Degradation. Center for Tropical Marine Ecology, Bremen, 109 pp.

Kselik, R.A.L., Smilde, K.W., Ritzema, H.P., Subagyono, K., Saragih, S., Damanik, M. \& Suwardjo, H. 1992. Integrated research on water management, soil fertility and cropping systems on acid sulphate soils in South Kalimantan, Indonesia. In: Dent, D.L. $\&$ van Mensvoort, M.E.F. (eds.), Selected $\mathrm{Pa}$ pers of the Ho Chi Minh City Symposium on Acid Sulphate Soils. ILRI Publication 53. International Institute for Land Reclamation and Improvement, Wageningen, p. 177194.

Law, W.M. \& Tan, M.M. 1977. Chemical properties of some Peninsular Malaysian soil series. In: Proceedings of Chemistry and Fertility of Tropical Soils. Malaysian Society of Soil Society, Kuala Lumpur, p. 180191.

Lin, Y.P. 2008. Simulating spatial distributions, variability and uncertainty of soil arsenic by geostatistical simulations in geographic information systems. Open Environmental Sciences, 2: 26-33.

Lin, Y.P., Chang, T.K., \& Teng, T.P. 2001 . Characterization of soil lead by comparing sequential Gaussian simulation, simulated annealing simulation and kriging methods. Environmental Geology, 41 : 189-199.

Liu, D., Wang, Z., Zhang, B., Song, K., Li, X., Li, J., Li, F., \& Duan, H. 2006. Spatial distribution of soil organic carbon and analysis of related factors in croplands of the black soil region, Northeast China. Agriculture, Ecosystems and Environment, 113: 73-81.

Madyaka, M. 2008. Spatial Modelling and Prediction of Soil Salinization Using SaltMod in a GIS Environment. Master of Science Thesis. International Institute for Geo-Information Science and Earth Observation, Enschede, the Netherlands, $128 \mathrm{pp}$.

McElnea, A.E. \& Ahern, C.R. 2004a. KCl extractable $\mathrm{pH}\left(\mathrm{pH}_{\mathrm{KC}}\right)$ and titratable actual acidity (TAA). In: Acid Sulfate Soils Laboratory Methods Guidelines. Queensland Department of Natural Resources, Mines and Energy, Indooroopilly, Queensland, Australia, p. B21-B2-3.

McElnea, A.E. \& Ahern, C.R. 2004b. Peroxide $\mathrm{pH}\left(\mathrm{pH}_{\mathrm{ox}}\right)$, titartable peroxide acidity (TPA) and excess acid neutralising capacity $\left(\mathrm{ANC}_{\mathrm{E}}\right)$. In: Acid Sulfate Soils Laboratory Methods Guidelines. Queensland Department of Natural Resources, Mines and Energy, Indooroopilly, Queensland, Australia, p. B3-1-B3-7.

McElnea, A.E. \& Ahern, C.R. 2004c. Sulfurperoxide oxidation method. In: Acid Sulfate Soils Laboratory Methods Guidelines. Queensland Department of Natural Resources, Mines and Energy, Indooroopilly, Queensland, Australia, p. B7-1-B7-2.

McElnea, A.E. \& Ahern, C.R. 2004d. Sulfur 1 M $\mathrm{KCl}$ extraction $\left(\mathrm{S}_{\mathrm{KC}}\right)$. In: Acid Sulfate Soils Laboratory Methods Guidelines. 
Queensland Department of Natural Resources, Mines and Energy, Indooroopilly, Queensland, Australia, p. B8-1-B8-2.

McElnea, A.E., Ahern, C.R., \& Menzies, N.W. 2002a. Improvements to peroxide oxidation methods for analysing sulfur in acid sulfate soils. Australian J. of Soil Research 40: 1,115-1,132.

McElnea, A.E., Ahern, C.R., \& Menzies, N.W. $2002 \mathrm{~b}$. The measurement of actual acidity in acid sulfate soils and the determination of sulfidic acidity in suspension after peroxide oxidation. Australian J. of Soil Research 40: 1133-1157.

Melville, M.D. 1993. Soil Laboratory Manual. School of Geography, The University of New South Wales, Sydney, 74 pp.

Menon, R.G. 1973. Soil and Water Analysis: A Laboratory Manual for the Analysis of Soil and Water. Proyek Survey O.K.T. South Sumatra, Palembang, $190 \mathrm{pp}$.

Muir, J.F. \& Kapetsky, J.M. 1988. Site selection decisions and project cost: the case of brackishwater pond systems. In: Aquaculture Engineering Technologies for the Future. Hemisphere Publishing Corporation, New York, p. 45-63.

Mustafa, A. 2007. Improving Acid Sulfate Soils for Brackishwater Ponds in South Sulawesi, Indonesia. Ph.D. Thesis. The University of New South Wales, Sydney, 418 pp.

Mustafa, A. \& Rachmansyah. 2008. Kebijakan dalam pemanfaatan tanah sulfat masam untuk budidaya tambak. Dalam: Sudradjat, A., Rusastra, I.W., \& Budiharsono, S. (eds.), Analisis Kebijakan Pembangunan Perikanan Budidaya. Pusat Riset Perikanan Budidaya, Jakarta, p. 1-11.

Mustafa, A., Rachmansyah, \& Hanafi, A. 2007. Kelayakan Lahan untuk Budi Daya Perikanan Pesisir. Dalam: Kumpulan Makalah Bidang Riset Perikanan Budidaya. Disampaikan pada Simposium Kelautan dan Perikanan, 7 Agustus 2007, Gedung Bidakara, Jakarta. Pusat Riset Perikanan Budidaya, Jakarta, $28 \mathrm{pp}$.

Mustafa, A. \& Sammut, J. 2007. Effect of different remediation techniques and dosages of phosphorus fertilizer on soil quality and klekap production in acid sulfate soilaffected aquaculture ponds. Indonesian Aquaculture J., 2(2): 141-157.

Noor, M. 2004. Lahan Rawa: Sifat dan Pengelolaan Tanah Bermasalah Sulfat Masam. PT Raja Grafindo Persada, Jakarta, 238 p.
Patrick, W.H.Jr. \& Delaune, R.D. 1977. Chemical and biological redox systems affecting nutrient availability in the coastal wetlands. Geoscience and Man, 18:131 137.

Pons, L.J. 1973. Outline of genesis, characteristics, classification and improvement of acid sulphate soil. In: Dost, H. (ed.), Acid Sulphate Soils. ILRI Publication 18. International Institute for Land Reclamation and Improvement, Wageningen, p. 1-27.

Robinson, T.P. \& Metternicht, G. 2006. Testing the performance of spatial interpolation techniques for mapping soil properties. Computer and Electronics in Agriculture, 50: 97-108.

Rossi, R.E., Mulla, D.J., Journel, A.G., \& Franz, E.H. 1992. Geostatistical tools for modeling and interpreting ecological spatial dependence. Ecological Monographs, 62: 277 314.

de Queiroz, J.F., Nicolella, G., Wood, C.W., \& Boyd, C.E. 2004. Lime application methods, water and bottom soil acidity in fresh water fish ponds. Scientia Agricola, 61(5) Piracicaba Sept./Oct.

Rachmansyah, Mustafa, A., \& Paena, M. 2010. Karakteristik, kesesuaian dan pengelolaan lahan tambak di Kota Pekalongan Provinsi Jawa Tengah. J. Ris. Akuakultur, 6(3): 502521.

Salam, M.A., Ross, L.G., \& Beveridge, C.M.M. 2003. A comparison of development opportunities for crab and shrimp aquaculture in southwestern Bangladesh, using GIS modeling. Aquaculture, 220: 477-494.

Sammut, J. 1999. Amelioration and management of shrimp ponds in acid sulfate soils: key researchable issues. In: Smith, P.T. (ed.), Towards Sustainable Shrimp Culture in Thailand and the Region. ACIAR Proceedings No. 90. Australian Centre for International Agricultural Research, Canberra, p. 102106.

Soil Survey Staff. 2001. Soil Taxonomy, a Basic System of Soil Classification for Making and Interpreting Soil Survey. United State Department of Agriculture, Washington, D.C., $734 \mathrm{pp}$.

Sokal, R.R. \& Rohlf, F.J. 1981. Biometry: The Principles and Practice of Statistics in Biological Research. Second edition: W.H. Freeman and Co., New York, 859 pp.

Sulaeman, Suparto, \& Eviati. 2005. Petunjuk Teknis Analisis Kimia Tanah, Tanaman, Air, dan Pupuk. Diedit oleh: Prasetyo, B.H., 
Santoso, D., \& Widowati, L.R. Balai Penelitian Tanah, Bogor, $136 \mathrm{pp}$.

Sunarto. 2008. Peranan Ekologis dan Antropogenesis Ekosistem Mangrove. Karya Ilmiah. Fakultas Perikanan dan IImu Kelautan, Universitas Padjadjaran, Jatinangor, $34 \mathrm{pp}$.

Treece, G.D. 2000. Site selection. In: Stickney, R.R. (ed.), Encyclopedia of Aquaculture. John Wiley \& Sons, Inc., New York, p. 869-879.

Tu, S.X., Guo, Z.F., \& Chen, S.S. 1993. Transformation of applied phosphorus in a calcareous fluvisol. Pedosphere, 3: 277-283.

Yost, R.S., Uehara, G., \& Fox, R.L. 1982. Geostatistical analysis of soil chemical properties of large land areas. II. Kriging.
Soil Science Society of American J., 46: 1,033-1,037.

Zare-Mehrjardi, M., Taghizadeh-Mehrjardi, R., \& Akbarzadeh, A. 2010. Evaluation of geostatistical techniques for mapping spatial distribution of soil $\mathrm{pH}$, salinity and plant cover affected by environmental factors in Southern Iran. Notulae Scientia Biologicae, 2(4): 92-103.

Zuo, X.A., Zhao, H.L., Zhao, X.Y., Zhang, T.H., Guo, Y.R., Wang, S.K., \& Sam, D. 2008. Spatial pattern and heterogenity of soil properties in sand dunes under grazing and restoration in Horqin Sandy Land, Northern China. Soil and Tillage Research, 99: 202-212. 